\title{
Sustainability of Organic Agriculture System by Plant Growth Promoting Rhizobacteria (PGPR)
}

\author{
Slamet Santosa ${ }^{1}$, Edi Purwanto ${ }^{2}$, Suranto ${ }^{3}$, Sajidan $^{4}$ \\ ${ }^{1,4}$ Department of Biology Education, Sebelas Maret University \\ ${ }^{2}$ Department of Agrotechnology, Sebelas Maret University \\ ${ }^{3}$ Department of Biology, Sebelas Maret University \\ ${ }^{1}$ Corresponding email: slametsantosa@ staff.uns.ac.id
}

\begin{abstract}
One of the problems for the sustainability of agriculture systems is the excessive use of inorganic fertilizers. This affects the conditions of soil biology, soil chemistry, and irrigation water. Solution for supporting the sustainability of the agriculture system is the application of organic agriculture. Organic agriculture is supported by the existence of plant growth promoting rhizobacteria. This research aimed to identifying isolates of plant growth promoting rhizobacteria, analyzing the conditions of paddy field soil chemistry and irrigation water. Samples were taken by random sampling. Bacterial identification was performed by dilution, planting on the media, quadrant digging, morphology test, gram staining, and DNA sequencing. The results showed that organic agriculture obtained Pseudomonas, Pantoea, Stenotrophomonas, Serratia, Exiguobacterium, Acinetobacter, and Bacillus. Inorganic agriculture obtained Pseudomonas and Bacillus. Comparison of soil chemistry quality in agriculture systems of organic: inorganic are showing organic C (1.9\%:1.4\%), N (0.37\%:0.24\%), P (11.64 ppm:10.81 ppm), K (0.28 \%:0.23\%), and pH (6.58:6.26). Comparison of irrigation water quality in agriculture systems of organic: inorganic are showing DO (7.6 ppm:6.4 ppm), COD (49 ppm:26 ppm), BOD (8.8 ppm:2.1 ppm), TSS (25 ppm:48 ppm), Pb metals $(<0.0161 \mathrm{ppm}:<0.0161 \mathrm{ppm})$, and Cr-VI metals $(<0.0014 \mathrm{ppm}:<0.0014 \mathrm{ppm})$.
\end{abstract}

Keywords: Irrigation Water, Organic Agriculture, Plant Growth Promoting Rhizobacteria, Soil Chemistry

\section{Introduction}

Sukorejo Village is one of the village where located at Sambirejo Subdistrict, Sragen Regency which has a large agriculture area, so most of the livelihood of the population is farming [6]. Sukorejo is located at $7^{\circ} 30^{\prime} 36.45^{\prime \prime}$ $\mathrm{S}-111^{\circ} 8^{\prime} 13.15^{\prime \prime} \mathrm{E}$. The type of plant grown is rice (Oryza sativa L.), especially IR 64 varieties. Rice var. IR 64 has resistance to leaf blight disease, leafhoppers, productive tillers, and conserves water consumption (Khaeruni, Najamuddin, Wijayanto, and S. Syair, 2016). Sukorejo village has an inorganic and organic agriculture systems.

The problem that occur is the excessive use of inorganic fertilizer, which can disrupt the sustainability of agriculture systems. Inorganic fertilizer is produced by the fertilizer industry. Inorganic fertilizers also causes the ground hardens, thereby decreasing porosity, oxygen availability, and existence of soil bacteria (Suntoro, 2010).

Utilizing chemical fertilizers and pesticides causes a decrease in environmental quality and productivity. In addition, affect the quality of soil chemistry and irrigation water parameters (Sanchez, et al, 2007). Residues of chemical substances left in the soil may be transported by crop production and human consumption may interfere with health (Liu, Shen, Liu, and Wang, 2007). Solution to maintaining the sustainability of agriculture is by the application of organic or semiorganic agriculture systems (Suntoro, 2010).

Organic agriculture are promising for environmental sustainability and less depletion of $\mathrm{N}, \mathrm{P}$, and $\mathrm{K}$ elements in the soil (Nuryani, and Widya, 2010). Using organic fertilizer plays a role to improve the quality of land. Using organic matters into soil can improve the physical, chemical, and biological conditions of the soil (Masykuri, and Rosariastuti, 2017). In addition, the role of soil microorganisms is very important.

Effective microorganisms are supporting the implementation of environmentally friendly agriculture, decomposition of organic matters, mineralization of organic compounds, fixation and nutrient solvents. Soil microbes are seen as one of the indicators in determining the soil quality index (Karlen, et al, 2006). Organic fertilizers become a source of nutrients for fungi, bacteria, and other beneficial microorganisms (Hadisuwito, 2008).

Microorganisms in the root areas (rhizobacteria) are capable of secreting a 
compound and beneficial for plant fertility (Verma, et al, 2010). Therefore, it is necessary to discover and develop potential of rhizobacteria as soil and plant fertilizers (Gupta, Gopal, and Tilak, 2015). Soil fertilizer microbes can improve fertilizer efficiency, fertility, and soil health (Bhattacharyya and Jha, 2012). This micro organism is called plant growth promoting rhizobacteria (PGPR).

Plant growth promoting rhizobacteria (PGPR) has several advantages, i.e. 1). biostimulants by synthesizing and regulating the concentrations of various phytohormones in the root environment; 2). biofertilizer by binding $\mathrm{N} 2$ from the air and dissolving the bound phosphate in the soil; 3). control of pathogens derived from the soil (bioprotectans) by producing various antipatogenic compounds or metabolites such as siderophore, $\beta$-1,3-glucanase, chitinase, antibiotics, and cyanide (Egamberdiyeva, 2007 and Yolanda, et al, 2011).

Based on the problems that arise due to the condition of inorganic agriculture, it is necessary environmentally friendly efforts by utilizing local microbials in agriculture areas in Sukorejo Village. This research aimed to identifying isolates of plant growth promoting rhizobacteria, analyzing the conditions of paddy field soil chemistry and irrigation water.

\section{Method}

Bacterial identification was performed by dilution, planting on the media, quadrant digging, morphology test, gram staining, and DNA sequencing. Material of soil sample around root of rice, aquades, nutrient agar, nutrient broth, $\mathrm{NaCl}$, yeast extract, pepton, safranin, violet crystal, carbohydrate/phenol red broth (maltose, glucose, lactose), aluminum foil, motility test medium, Simon Citric Agar (SCA), MgSO47H2O, (NH4)2HPO4, K2HPO4, citric acid, Triple Sugar Iron (TSI) gelatine, NH4FeCitric, $\mathrm{Na} 2 \mathrm{~S} 2 \mathrm{O} 3$, alcohol $70 \%$, MT-3 gelatine, bacterial DNA isolation kit Primary set (for bacteria).

Soil chemistry parameters studied were $\mathrm{C}$ Organic (Walkley \& Black), N (Kjeldhal Method), $\mathrm{P}$ available (Olsen), $\mathrm{K}$ Exchanged Ex. NH4Oac $1 \mathrm{~N} \mathrm{pH} \mathrm{7,} \mathrm{and} \mathrm{pH} \mathrm{(H2O).}$

Irrigation water quality parameters of observed were DO (SNI 6989.72-2009), COD (SNI 6989.2-2009), BOD (SNI 6989.72-2009), TSS (In House Methods), Pb (SNI 6989.8-
2009), and Cr-VI (APHA 2012, Section 3500$\mathrm{Cr})$.

\section{Results and Discussion \\ 3.1. Existences of PGPR}

Table 1. PGPR Findings

\begin{tabular}{lll}
\hline No. & \multicolumn{1}{c}{ Organic } & \multicolumn{1}{c}{ Inorganic } \\
\hline 1. & Pseudomonas & Pseudomonas \\
2. & Bacillus & Bacillus \\
3. & Pantoea & \\
4. & Stenotrophomonas & \\
5. & Acinetobacter & \\
6. & Serratia & \\
7. & Exiguobacterium & \\
\hline
\end{tabular}

Pseudomonas contribute to degradation of hydrocarbon pollution (Junaidi, Muyassir, and Syafruddin, 2013). Hydrocarbon contamination in agricultural land caused by pesticides and chemical fertilizers Several species of Pseudomonas produce fitohormon, including $P$. aeruginosa producing auxin, $P$. tabaci producing ethylene, and $P$. fluorescens producing IAA (Verma, et al, 2013). Pseudomonas converting organic phosphate to inorganic phosphate and produces siderophore for plant growth (Aarab, et al, 2015).

Bacilllus cereus produce phytohormones, khitinase, and suppresses the life of fungal pathogen (Ashour, et al, 2016). B. licheniformis, B. pumilus, B. megaterium, and $B$. subtilis may produce phytohormones of IAA, gibberellin, ethylene, increase nutrients by dissolving phosphate (Elkoca, et al, 2008 and Verma, et al, 2010) and increasing uptake of $\mathrm{N}, \mathrm{P}, \mathrm{K}$, and $\mathrm{Fe}$ (Ma, Gao, Li, and Zhang, 2014). Pantoea agglomerans secrete phytat acid hydrolysis enzymes to form D-myoinositol $(1,2,4,5,6)$ pentakis phosphate in soil enrichment, especially phosphate (Greiner and Sajidan, 2008). Stenotrophomonas controlling pests and increase plant growth (El-Sayed, 2014 and Chen, et al, 2009). Stenotrophomonas plays a role in the degradation of pesticides that pollute the soil (Puspitasari and Khaeruddin, 2016).

Acinetobacter dissolves phosphate in the soil and produces organic acids, thus helping to fertilize the soil). Acinetobacter calcoaceticus SE370 can promote plant growth by secreting gibberellins and by converting insoluble soil $\mathrm{P}$ to soluble forms which are readily available to the plant (Kang, et al, 
2009). Serratia marcescens potential as biological control agent of plant pathogenic bacteria because Serratia produces prodigiosin, the secondary metabolite as antibacterial, antifungal, and antiprotozoal (Priyatno, et al, 2011). Exiguobacterium plays a role in the metal pollutants bioreduction, one of which is Cr (VI) in soil (Alam and Malik, 2008). Exiguobacterium on agriculture land plays a role in increasing phosphate solubility at optimum pH (Kumar, Bhargava, and Rai, 2010).

PGPR are found in organic agriculture more than inorganic. PGPR has the potential to support the sustainability of organic agriculture systems because it has a high diversity, acts as biostimulant, biofertilizer, and control of pathogenic organisms.

\subsection{Soil Chemistry Quality}

Table 2. Soil Chemistry Content

\begin{tabular}{|c|c|c|}
\hline Parameters & $\begin{array}{c}\text { Organic } \\
\text { (Status*) }\end{array}$ & $\begin{array}{c}\text { Inorganic } \\
\text { (Status*) }\end{array}$ \\
\hline $\begin{array}{l}\mathrm{C} \text { organic } \\
(\%)\end{array}$ & 1.9 (Low) & 1.4 (Low) \\
\hline $\mathrm{N}(\%)$ & $\begin{array}{r}0.37 \\
\text { (Medium) }\end{array}$ & $\begin{array}{r}0.24 \\
\text { (Medium) }\end{array}$ \\
\hline $\mathrm{P}(\mathrm{ppm})$ & $\begin{array}{r}11.64 \\
\text { (Medium) }\end{array}$ & 10.81 (Low) \\
\hline $\begin{array}{l}\mathrm{K}(\%) \\
\mathrm{pH}\end{array}$ & $\begin{array}{r}0.28 \text { (Low) } \\
6.58 \\
\text { (Neutral) }\end{array}$ & $\begin{array}{r}0.23 \text { (Low) } \\
6.26 \\
\text { (Neutral) }\end{array}$ \\
\hline
\end{tabular}

The low of $\mathrm{C}$ organic content is caused by an imbalance between the role of the material and the loss of organic matters from the soil. C Organic indicates the content of organic matters in the soil which is the land management measure (Rosariastuti, Hartati, Widijanto, and Utomo, 2012). Soil N content comes from organic matters, binding by microorganisms from air nitrogen, fertilizers, and rainwater (Hardjowigeno, 2003) . Nitrogen stimulating the growth of plants in the vegetative phase, formation of chlorophyll, amino acids, fats, and enzymes.

Utilities of $\mathrm{P}$ are essential for cell growth, root formation and root hair, strengthening straw, improving crop quality, growth of seed and plant organ, and strengthening disease resistance. The availability of $\mathrm{K}$ that can be interchangeable and can be absorbed by the plant depends on the addition of the outside, the fixation by the soil and the addition of its own K. Soil acidity $(\mathrm{pH})$ greatly affects the development of microorganisms in the soil. At $\mathrm{pH}$ 5-5.7, bacteria and fungi break down organic materials can thrive (Suntoro, 2010).

Some chemistry soil parameters on organic agriculture are included in the low and medium category due to the process of soil improvement effect of chemical fertilizers in the previous agriculture. The process of improving the condition of the land takes time (Suntoro, 2010). The implementation of organic agriculture is expected to support the sustainability of environmentally friendly agriculture.

\subsection{Irrigation Water Quality}

Table 3. Irrigation Water Quality

\begin{tabular}{lrr}
\hline Parameters & \multicolumn{1}{c}{$\begin{array}{c}\text { Organic } \\
\text { (Class*) }\end{array}$} & \multicolumn{1}{c}{$\begin{array}{c}\text { Inorganic } \\
\text { (Class*) }\end{array}$} \\
\hline DO $(\mathrm{ppm})$ & $7.6(\mathrm{I})$ & $6.4(\mathrm{I})$ \\
$\mathrm{COD}(\mathrm{ppm})$ & $49(\mathrm{II})$ & $26(\mathrm{II})$ \\
$\mathrm{BOD}(\mathrm{ppm})$ & $8.8(\mathrm{III})$ & $2.1(\mathrm{I})$ \\
TSS $(\mathrm{ppm})$ & $25(\mathrm{I})$ & $48(\mathrm{I})$ \\
$\mathrm{Pb}(\mathrm{ppm})$ & $<0.0161(\mathrm{I})$ & $<0.0161(\mathrm{I})$ \\
$\mathrm{Cr} \quad(\mathrm{VI})$ & $<0.0014(\mathrm{I})$ & $<0.0014(\mathrm{I})$ \\
(ppm) & & \\
(Peraturan Pemerintah, 2001)
\end{tabular}

Based on Table 3, it is known that the COD content in organic agriculture is higher than inorganic farming. This is due to the total amount of organic matter contained in the waters, both biodegradable and difficult to decompose (Lofrano, Meric, Zengin, and Orhon, 2013). BOD content in organic farming is higher than inorganic farming. This is due to the amount of oxygen needed by microorganisms to oxidize the organic material in the water is high (Ma, Gao, Li, and Zhang, 2014). The quality of irrigation water used in both agricultural systems is in a decent category. However, keep in mind that organic agriculture is more environmentally friendly than inorganic.

\section{Conclusions}

Conclusions of this research are 1). organic farming obtained isolates Pseudomonas, Pantoea, Stenotrophomonas, Serratia, Exiguobacterium, Acinetobacter, and Bacillus, inorganic agriculture obtained Pseudomonas and Bacillus; 2). Comparison of 
soil chemistry on organic agriculture:inorganic are organic C (1.9\%: $1.4 \%), \mathrm{N}(0.37 \%: 0.24$ $\%), \mathrm{P}$ (11.64 ppm: $10.81 \mathrm{ppm}), \mathrm{K}(0.28 \%$ : $0.23 \%)$, and $\mathrm{pH}$ (6.58:6.26), and 3$)$. Comparison of irrigation water quality in organic farming: inorganic are DO (7.6 ppm: 6.4 ppm), COD (49 ppm: 26 ppm), BOD (8.8 ppm: $2.1 \mathrm{ppm})$, TSS (25 ppm: $48 \mathrm{ppm}), \mathrm{Pb}$ $(<0.0161$ ppm: $<0.0161 \mathrm{ppm})$, and Cr-VI $(<0.0014$ ppm: $<0.0014$ ppm).

\section{References}

A. Gulati, N. Sharma, P. Vyas, S. Sood, P. Rahi, V. Pathania, and R. Prasad, Organic acid production and plant growth promotion as a function of phosphate solubilization by Acinetobacter rhizosphaerae strain BIHB 723 isolated from the cold deserts of the trans-Himalayas, Arch Microbiol. 192 (2010), pp. 975-983.

A. Gupta, M. Gopal, and K.V. Tilak, Mechanism of plant growth promotion by rhizobacteria, Indian J. Exp. Biol. 38 (2015), pp. 856-862.

A. Khaeruni, E. Najamuddin, T. Wijayanto, and S. Syair, Ketahanan berbagai kultivar padi local terhadap penyakit hawar daun bakteri, Jurnal Fitopatologi Indonesia, 12 (3) (2016), pp. 89-95.

A. Kumar, P. Bhargava, and L.C. Rai, Isolation and molecular characterization of phosphate solubilizing Enterobacter and Exiguobacterium species from paddy fields of Eastern Uttar Pradesh, India, African Journal of Microbiology Research, 4(9) (2010), pp. 820-829.

A.C. Aji, M. Masykuri, and R. Rosariastuti, Phytoremediation of rice field contaminated by chromium with mendong (Fimbristylis globulosa) to supporting sustainable agriculture, Proceeding, The $3^{\text {rd }}$ International Indonesian Forum for Asian Studies: Borderless Communities \& Nation with Borders Challenges of Globalisation, (2017), pp. 1236-1247.

Badan Pusat Statistik Kabupaten Sragen, Sragen Dalam Angka, (Sragen: Badan Pusat Statistik, 2017).

Balai Penelitian Tanah, Analisis kimia Tanah, Tanaman, Air, dan Pupuk: Petunjuk
Teknis Edisi 2, (Bogor: Balai Penelitian Tanah Press, 2009).

D. Egamberdiyeva, The effect of PGPR on growth and nutrient uptake of maize in two different soils. Applied Soil Ecology, 36 (1) (2007), pp. 184-189.

D.J., Puspitasari and Khaeruddin, Kajian bioremediasi pada tanah tercemar pestisida, Kovalen, 2(3) 2016 pp. 98106.

D.L. Karlen, E.G. Hurley, S.S. Andrews, C.A. Cambardella, D.W. Meek, M.D. Duffy, and A.P. Mallarino, Crop rotation effects on soil quality at Three Northern Corn/Soybean Belt Locations, Agronomy Journal Abstract-Soil Quality and Fertility, 98 (3) (2006), pp. 484-495.

D.S. Powlson, P.J. Gregory, W.R. Whalley, J.N. Quinton, D.W. Hopkins, A.P. Whitmore, P.R. Hirsch, and K.W.T. Goulding, Soil management in relation to sustainable agriculture and ecosystem services, Food Policy, 36 (2011), pp. 572-587.

E. Elkoca, F. Kantar, and F. Sahin, Influence of nitrogen fixing and phosphate solubilizing bacteria on nodulation, plant growyh and yield of chickpea, $J$. Plant Nutr. 33 (2008), pp. 157-171.

E.M.G. Yolanda, D.J. Hernandez, C.A. Hernandez, M.A.M. Esparza, M.B. Cristales, L.F. Ramirez, R.D.M. Contreras, and J.M. Rojas, Growth response of maize plantlets inoculated with Enterobacter spp. as a model for alternative agriculture, Revista Argentina de Microbiología, 4 (3) (2011), pp. 287-293.

E. Sanchez, M.F. Colmenarejo, J. Vicente, A. Rubio, M.G. Garcia, L. Travieso, and R. Borja, Use of the water quality index and dissolved oxygen deficit as simple indicators of watersheds pollution, Ecological Indicators, 7 (2007), pp. 315-328.

G. Lofrano, S. Meric, G.E. Zengin, and D. Orhon, Chemical and biologicaltreatment technologies for leather tannery chemicals and wastewater: A review, Science of the Total Environmental, 461 (2013), pp. 265-281.

J.C. Biswas, J.K. Ladha, F.B. Dazzo, Y.G. Yanni, and B.G. Rolfe, Rhizobial 
inoculation influences seedling vigor and yield of rice, Agron J. 92 (2000), pp. 880-886.

J. Ma, X. Lv, D. Gao, Y. Li, B. Lv, and J. Zhang, Nanocomposite-based green tanning process of suede leather to enhance chromium uptake, Journal of Cleaner Production, 71 (2014), pp. 120-126.

J.P. Verma, J. Yadav, K.N. Tiwari, Lavakush, and V. Singh, Impact of plant growth promoting rhizobacteria on crop production, International Journal of Agricultural Research, 5 (11) (2010), pp. 954-983.

Junaidi, Muyassir, and Syafruddin, Penggunaan bakteri Pseudomonas fluorescens dan pupuk kandang daalam bioremediasi inceptisol tercemar hidrokrbon, Jurnal Konservasi Sumber Daya Lahan, 1(1), 2013, pp.1-9.

M.Z. Alam and A. Malik, Chromate resistance, transport and bioreduction by Exiguobacterium sp. ZM-2 isolated from agricultural soil irrigated with tannery effluent, Journal of Basic Microbiology, 48 (2008), pp. 416-420.

N.A.S. Messiha, A.D. van Diepeningen, N.S. Farag, S.A. Abdallah, J.D. Janse, and A.H.C. van Bruggen, Stenotrophomonas maltophilia: a new potential biocontrol agent of Ralstonia solanacearum, causal agent of potato brown root, Eur. J. Plant Pathol. 118 (2007), pp. 211-225.

Peraturan Pemerintah Nomor 82 Tahun 2001 tentang Pengelolaan Kualitas Air dan Pengendalian Pencemaran Air

P.N. Bhattacharyya and D.K. Jha, Plant growth-promoting rhizobacteria (PGPR): emergence in agriculture. World J Microbiol Biotechnol, 28(2012), pp. 1327-1350.

P. Verma, A.N. Yadav, S.K. Kazy, A.K. Saxena, and A. Suman, Evaluating the diversity and plant growth promoting attributes of wheat (Triticum aestivum) associated acidotolerant bacteria from southern hills zone of India, Natl J Life Sci. 10 (2) (2013), pp. 219-226.

R. Greiner and Sajidan, Production of D-myoinositol (1, 2, 4, 5, 6) pentakis phosphate using alginate-entrapped recombinant Pantoea agglomerans glucose-1-phosphatase, Brazilian
Archives of Biology and Technology, 51 (2) (2008).

R. Rosariastuti, S. Hartati, H. Widijanto, and E.W. Utomo, Evaluasi kesuburan kimia tanah di lahan kering sub daerah aliran sungai samin Kabupaten Karanganyar, Jurnal Ilmu Tanah dan Agroklimatologi, vol. 9 (2012), pp. 3950.

S. Aarab, F.J. Ollero, M. Megias, A. Laglaoui, M. Bakkali, and A. Arakrak, Isolation and screening of bacteria from rhizospheric soils of rice fields in Northwestern Morroco for different plant growth promotion (PGP) activities: An in vitro study. Int. $J$. Curr. Microbiol. App. Sci, 4 (1) (2015), pp. 260-269.

S. Hadisuwito, Membuat Pupuk Kompos Cair, (Jakarta: PT Agromedia Pustaka, 2008).

S. Hardjowigeno, Ilmu Tanah, (Jakarta: Akademika Pressindo, 2003).

S.H.U. Nuryani, M. Haji, and N.Y. Widya, Serapan hara N, P, K pada tanaman padi dengan berbagai lama penggunaan pupuk organik pada vertisol Sragen, Jurnal Ilmu Tanah dan Lingkungan, 10 (1) (2010), pp. 1-13.

S.M. Kang, G.J. Joo, M. Hamayun, C.I. Na, D.H. Shin, H.Y. Kim, J.K. Hong, and I.J. Lee, Gibberellin production and phosphate solubilization by newly isolated strain of Acinetobacter calcoaceticus and its effect on plant growth, Biotechnol Lett, 31 (2009), pp. 277-281.

Suntoro, Manajemen Sumber Daya Lahan Ramah Lingkungan, (Surakarta: Universitas Sebelas Maret (UNS) Press, 2010).

S.W. El-Sayed, A. Akhkha, M.Y. El-Naggar, and M. Elbadry, In vitro antagonistic activity, plant growth promoting traits and phylogenetic affiliation of rhizobacteria associated with wild plants grown in arid soil, Front. Microbiol. 5 (651) (2014).

T.P. Priyatno, Y.A. Dahliani, Y. Suryadi, I.M. Samudra, D.N. Susilowati, I. Rusmana, B.S. Wibowo, and C. Irwan, Identifikasi entomopatogen bakteri merah pada wereng batang coklat (Nilaparvata lugens Stal.), Jurnal AgroBiogen, 7 (2) (2011), pp. 85-95. 
W.E. Ashour, E.R. Hamed, A.I. El-Diwany, M.A. Swelim, and A.A.A. El Aty, Isolation and characterization of plant growth-promoting rhizobacteria from Trigonella foenum-graecum $L$ rhizosphere and evaluation of their potential substances produced, Research Journal of Pharmaceutical, Biological and Chemical Sciences, 7 (3) (2016), pp. 130.

W.X. Liu, L.F. Shen, J.W. Liu, and Y.W. Wang, Uptake of toxic heavy metals by rice (Oryza sativa L.) cultivated in the agricultural soil near Zhengzhou City, People's Republic of China, Bull Environ Contam Toxicol. 79 (2007), pp. 209-213.

X.H. Chen, A. Koumoutsi, R. Scholz, K. Schneider, J. Vater, and R. Süssmuth, Genome analysis of Bacillus amyloliquefaciens FZB42 reveals its potential for biocontrol of plant pathogen, J. Biotechnol. 140 (2009), pp. 27-37. 